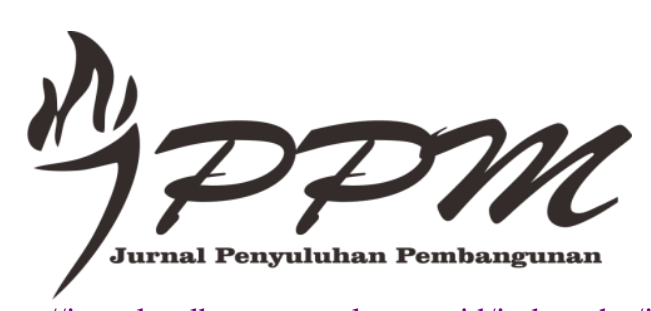

http://jurnal.polbangtanmalang.ac.id/index.php/jppm

Jurnal Penyuluhan Pembangunan Volume 1, Nomor 1 Tahun 2019

\title{
Kapasitas Petani Padi dalam Penerapan Teknologi Pengelolaan Tanaman Terpadu (PTT) di Kecamatan Tamansari Kabupaten Bogor Jawa Barat
}

\section{Capacity of Paddy Farmers in the Application of Integrated Crop Management Technology in Tamansari District, Bogor Regency, West Java}

\author{
Budi Sawitri $*^{1}$, Hatipah Nurtilawati ${ }^{2}$ \\ ${ }^{1}$ Program Studi Penyuluhan Pertanian Berkelanjutan, Polbangtan Malang \\ ${ }^{2}$ Penyuluh Pertanian Dinas Tanaman Pangan Hortikultura dan Perkebunan Kab. Bogor \\ e-mail: *1 budisawitri@ polbangtanmalang.ac.id
}

\begin{abstract}
Abstrak
Pengelolaan Tanaman Terpadu (PTT) merupakan suatu pendekatan inovatif dan dinamis sebagai upaya meningkatkan produksi dan pendapatan petani melalui perakitan teknologi secara partisipatif bersama petani. Teknologi ini ditetapkan untuk menjawab permasalahan sub sektor tanaman pangan yaitu adanya kesenjangan produktivitas ditingkat petani dibanding potensi yang dapat dicapai petani. Penerapan teknologi PTT ini akan efektif apabila petani memiliki kapasitas yang memadai pada kegiatan usahatani padi. Penelitian ini bertujuan untuk menganalisis tingkat kapasitas petani, faktor-faktor yang mempengaruhi kapasitas petani, dan pengaruh kapasitas terhadap keberlanjutan usaha. Hasil penelitian menunjukkan bahwa tingkat kapasitas petani cenderung rendah pada aspek pemecahan masalah, perencanaan usahatani dan adaptasi terhadap teknologi, sementara kemampuan teknis dan kemampuan mengevaluasi cenderung sedang. Kapasitas petani dipengaruhi secara positif oleh faktor eksternal yaitu dukungan penyuluhan dan peran kelompoktani. Dukungan penyuluhan direfleksikan oleh kesesuaian materi penyuluhan, intensitas penyuluhan dan kemampuan penyuluh. Sedangkan peran kelompoktani direfleksikan oleh keaktifan kelompok dalam menggerakkan anggota, wadah kerjasama, membantu pemasaran dan akses program bantuan baik dari pemerintah maupun swasta. Kapasitas petani berupa kemampuan pemecahan masalah, perencanaan dan evaluasi usahatani, serta adaptasi teknologi berpengaruh positif langsung terhadap keberlanjutan usahatani padi.
\end{abstract}

Kata kunci: kapasitas, keberlanjutan usaha, pengelolaan tanaman terpadu, padi 
Budi Sawitri dan Hatipah Nurtilawati, Kapasitas Petani Padi dalam Penerapan Teknologi Pengelolaan Tanaman Terpadu (PTT) di Kecamatan Tamansari Kabupaten Bogor Jawa Barat

\begin{abstract}
Integrated Crop Management (ICM) is an innovative and dinamic approach in an effort to increase farmers 'production and income through participatoty technology assembly with farmers. The technology is set to answer the problem of the food crop subsector, namely the productivity gap at the farmer level compared to the potential that can be achieved by farmers. The application of ICM technology will be effective if farmers have sufficient capacity in rice farming activities. This study aims to analyze the level of farmer capacity, factors that influence farmer capacity, and the influence of capacity on business sustainability. The results showed that farmers' capacity levels tended to be low on aspect of problem solving, farming planning and adaptation to technology, while technical capability and evaluation abilities tended to be moderate. The capacity of farmers is positively influenced by external factorts, namely extension support and the role of farmer groups. Extension support is reflected by the suitable of counseling materials, the intensity of counseling and the ability of counselors. Whereas the group role is reflected in the activeness of the group in mobilizing members, a forum for cooperation, helping with marketing, and access to assitance programs from both the goverment and the privat sector. The capacity of farmers in the form of problem solving skills, planning and evauation of farming, and technological adaptation have a direct positive effect on sustainability of rice farming.
\end{abstract}

Keywords: capacity, bussines sustainability, integrated crop management, paddy

\title{
I. PENDAHULUAN
}

Pengelolaan Tanaman Terpadu (PTT) padi sawah adalah suatu pendekatan inovatif dan dinamis dalam upaya meningkatkan produksi dan pendapatan petani melalui perakitan komponen teknologi secara partisipatif bersama petani (Balitbangtan 2016). Padi merupakan produk pertanian yang memiliki nilai strategis sehingga menjadi prioritas pengembangan sebagai upaya peningkatan kesejahteraan para petani. Walaupun faktanya, masyarakat Indonesia yang mayoritas petani masih menempati peringkat strata ekonomi dari menengah hingga bawah. Padahal saat ini permintaan pasar untuk pangan terutama beras terus meningkat.

Penerapan PTT oleh petani diharapkan dapat menghasilkan gabah dengan kualitas yang meningkat, penggunaan teknologi yang tepat guna, berkurangnya biaya usahatani padi, terjaganya kelestarian lingkungan tumbuh padi. Sejak tahun 2008 PTT telah diterapkan pada areal seluas 1,59 juta ha dengan melibatkan 60.000 kelompok tani di 32 provinsi (Balitbangtan 2009).

PTT padi berkaitan erat dengan adopsi teknologi. Adopsi dalam proses penyuluhan pertanian dapat dikatakan sebagai proses penerimaan inovasi atau perubahan prilaku baik berupa pengetahuan, sikap dan ketrampilan pada diri seserang setelah menerima inovasi dapat diamati secara langsung maupun tidak oleh orang lain (Mardikanto 1993).

Pendekatan pembangunan pertanian lebih mengutamakan aspek teknis dan kurang memperhatikan faktor manusia, menyebabkan rendahnya kemampuan petani dalam menghasilkan pangan (Aminah 2015). Transfer teknologi ke petani melalui 
Budi Sawitri dan Hatipah Nurtilawati, Kapasitas Petani Padi dalam Penerapan Teknologi Pengelolaan Tanaman Terpadu (PTT) di Kecamatan Tamansari Kabupaten Bogor Jawa Barat

penyuluhan belum sepenuhnya berorientasi pada pengembangan kapasitas petani dan mengabaikan pengetahuan lokal, serta sistem penelitian yang dilakukan tidak memperhitungkan keanekaragaman agroekologi, tidak sensitif terhadap umpan balik keberlanjutan teknologi dan tidak memperhatikan kapasitas penerapan teknologi (Leeuwis dan Van Den Ban 2009). Hal ini berdampak pada petani yang belum mampu bersaing dalam era globalisasi.

Usahatani padi dengan penerapan teknologi PTT akan mampu meningkatkan produksi dan produktivitas apabila petani memiliki kapasitas yang memadai. Peningkatan kapasitas akan sangat membantu dalam proses usahatani padi sehingga akan menghasilkan produk yang berkualitas dan lingkungan akan tetap terjada. Kapasitas petani merupakan kemampuan individu dalam melaksanakan fungsi manajemen usahatani secara efektif, efisien dan berkelanjutan dengan memanfaatkan potensi secara maksimal.

Terdapat beberapa kendala yang dihadapi petani dalam menjalankan usahatani dalam menerapkan teknologi PTT. Kendala tersebut terkait dengan penerapan teknik PTT, perencanaan dan evaluasi usahatani, adaptasi teknologi, dan penyelesaian permasalahan yang dihadapi oleh petani.

Dari beberapa permasalahan tersebut diatas peran sumberdaya manusia yang harus mendapat perhatian khusus, sebelum berorientasi pada produksi. Membangun konsep pada manusia merupakan tantangan dalam pembangunan pertanian, karena pengembangan sumberdaya manusia merupakan salah satu kunci utama kesinambungan suatu pembangunan. Meningkatkan kapasitas petani dalam usahatani khususnya padi sawah adalah salah satu solusi penting agar petani dapat berkontribusi untuk ketahanan pangan nasional.

Tujuan penelitian ini yaitu 1) menganalisis tingkat kapasitas petani dalam penerapan PTT pada usahatani padi sawah, 2) menganalisis faktor-faktor yang mempengaruhi kapasitas petani, dan 3) menanalisis pengaruh kapasitas petani terhadap keberlanjutan usahatani.

\section{METODE PENELITIAN}

Penelitian ini menggunakan metode survei dengan pendekatan kuantitatif serta didukung data kualitatif untuk mempertajam analisis data kuantitatif. Pengumpulan data primer dilakukan dengan teknik pengisian kuisioner dan diperdalam melalui teknik wawancara mendalam. Penelitian dilaksanakan di Kecamatan Tamansari Kabupaten Bogor, selama September sampai dengan Desember 2018.

Populasi pada penelitian ini adalah petani yang menjalankan usahatani padi yang sudah terdedah penyuluhan PTT padi sawah. Penentuan sampel wilayah dilakukan secara purposive dimana dipilih wilayah yang merupakan sentra pengembangan padi sawah. Wilayah ditetapkan di Desa Sukaresmi dan di Desa Sukamantri. Jumlah populasi petani padi sawah yang tergabung dalam kelompok tani dalam dua sampel wilayah yaitu 212 orang, penentuan sampel didasarkan pada prosentasi dari jumlah populasi yaitu sekitar $15-25 \%$, sehingga total sampel 42 orang.

Variabel dalam penelitian ini adalah karakteristik petani $\left(\mathrm{X}_{1}\right)$, dukungan penyuluhan $\left(\mathrm{X}_{2}\right)$, peran kelompok tani $\left(\mathrm{X}_{3}\right)$, kapasitas petani $\left(\mathrm{Y}_{1}\right)$ dan keberlanjutan usahatani $\left(\mathrm{Y}_{2}\right)$. Untuk mengukur pengaruh peubah bebas $(\mathrm{X})$ terhadap peubah terikat $(\mathrm{Y})$ dinyatakan dalam hipotesis penelitian. Variabel tersebut diukur dengan menggunakan 
Budi Sawitri dan Hatipah Nurtilawati, Kapasitas Petani Padi dalam Penerapan Teknologi Pengelolaan Tanaman Terpadu (PTT) di Kecamatan Tamansari Kabupaten Bogor Jawa Barat

analisis pendekatan Partial Least Square (PLS). Model yang dihasilkan berupa model pengukuran dan model struktural. Model pengukuran (outer model) dihasilkan melalui proses iterasi algoritma untuk menilai validitas dan reliabilitas indikator untuk mendapatkan parameter model pengukuran. Apabila nilai koefisien hasil $<0,5$ maka indikator tersebut harus dihilangkan dari model dan dilakukan satu persatu secara berulang sampai model akhir memiliki nilai koefisien $>0,5$. Penentuan nilai koefisien diatas 0,5 sebagai syarat agar dapat dilakukan proses bootstrapping untuk melihat signifikansi. Apabila nilai koefisien hasilnya $<0.5$ maka indikator tersebut harus dihilangkan dari model dan dilakukan satu persatu secara berulang sampai model akhir memiliki nilai koefisien >0.5 (Sarwono dan Narimawati 2015).

Model struktural (inner model) dihasilkan untuk menilai kekuatan estimasi antar variabel laten/konstruk melalui bootstrapping yaang kemudian dievaluasi menggunakan nilai $\mathrm{R}^{2}$ untuk mengukur tingkat variasi perubahan variabel independen terhadap variabel dependen. Semakin tinggi nilai $\mathrm{R}^{2}$ semakin baik model prediksi dari model penelitian yang diajukan.

\section{HASIL DAN PEMBAHASAN}

\section{Karakteristik Petani}

Karakteristik petani padi sawah menunjukkan bahwa umur berada pada usia lanjut, pendidikan rata-rata Sekolah Dasar (SD), pengalaman usahatani dibawah 13 tahun, dan kepemilikan luas lahan garapan rata-rata dibawah satu hektar (Tabel 1).

\section{Umur}

Mayoritas petani responden di wilayah penelitian berada pada kelompok umur lebih dari 50 tahun sehingga berada pada kategori kelompok usia lanjut dengan jumlah 59 persen. Seluruh responden adalah petani yang mengusahakan tanaman padi. Komposisi umur produktif hanya sejumlah 38 persen yang pada dasarnya mempunyai potensi untuk meningkatkan produktivitas kerja.

Kondisi umur petani diwilayah penelitian memang berada pada kategori usia lanjut menurut Havigurst (1974), hal ini dikarenakan bertani on farm hanya diminati oleh petani pada usia lanjut, sementara generasi muda lebih tertarik pada pertanian yang bersifat off farm. Umur seseorang berhubungan dengan tingkat kemampuan bekerja, secara ideal menurut Padillah et al.(2018) kemampuan bekerja pada usia produktif akan lebih tinggi dibandingkan dengan yang tidak produktif. Namun umur petani menurut Lodismith dan Robert (2010) mencerminkan berbagai pengalaman untuk menuju kesuksesan dalam hidup dengan ukuran kompetensi, kebahagiaan, jiwa yang sehat dan pekerjaan. Berdasarkan penyataan tersebut menunjukkan bahwa untuk mencapai kesejahteraan tidak harus berada pada usia produktif, namun pengalaman dan kompetensi yang dimiliki dapat menjadi landasan untuk menuju kesejahteraan.

\section{Tingkat Pendidikan}

Tingkat pendidikan yang dimiliki dapat mempengaruhi kemampuan petani dalam mengelola usahataninya. Sebagian besar petani yaitu sekitar 59,52 persen menempuh pendidikan formal di tingkat Sekolah Dasar. Hal ini menunjukkan bahwa petani di wilayah penelitian umumnya memiliki pendidikan Sekolah Dasar (SD). Walaupun 
Budi Sawitri dan Hatipah Nurtilawati, Kapasitas Petani Padi dalam Penerapan Teknologi Pengelolaan Tanaman Terpadu (PTT) di Kecamatan Tamansari Kabupaten Bogor Jawa Barat

Fatchiya (2010) mengatakan bahwa pendidikan merupakan suatu hal yang memiliki keterkaitan dengan seseorang dalam berpikir dan bertindak sesuai dengan kemampuannya, namun petani di Kecamatan Tamansari setidaknya memiliki kemampuan untuk mengadopsi teknologi, berkomunikasi dengan petugas penyuluh lapangan dalam menerima inovasi dan bersosialisasi serta bertukar informasi kepada petani lain tentang pengelolaan tanaman terpadu pada usahatani padi.

Tingkat pendidikan petani yang rata-rata rendah dikarenakan petani tidak melanjutkan pendidikan ke jenjang yang lebih tinggi karena kondisi ekonomi keluarga. Pada masa usia sekolah petani telah membantu orangtuanya untuk bekerja pada lahan usahatani sehingga akhirnya tidak melanjutkan sekolah ke jenjang yang lebih tinggi. Hal ini sebagaimana menurut Mirza et al. (2017), rendahnya tingkat pendidikan dapat menjadi penyebab rendahnya kemampuan anggota kelompok dalam pengelolaan usaha yang berkelanjutan. Diperkuat Aminah (2015) bahwa struktur pendidikan yang rendah menyiratkan rendahnya literasi, terbatasnya wawasan dan kreatifitas yang pada gilirannya akan menurunkan produktivitas petani menghasilkan produk pertanian dan tanaman pangan.

Tabel 1 Karakteristik Petani di Kecamatan Tamansari Kabupaten Bogor Tahun 2018

\begin{tabular}{|c|c|c|c|c|}
\hline $\begin{array}{c}\text { Potensi } \\
\text { Internal }\end{array}$ & Kategori & $\begin{array}{c}\text { Jumlah } \\
(n=42)\end{array}$ & $\begin{array}{c}\text { Persentase } \\
(\%)\end{array}$ & Rataan \\
\hline \multirow[t]{4}{*}{ Umur } & Remaja (<20 th) & 1 & 2,40 & 51,43 \\
\hline & Dewasa awal (20- <30 th) & 3 & 7,11 & \\
\hline & Usia pertengahan (30-50 th) & 13 & 30,96 & \\
\hline & Usia Lanjut (>50 th) & 25 & 59,53 & \\
\hline \multirow{4}{*}{$\begin{array}{c}\text { Tingkat } \\
\text { Pendidikan }\end{array}$} & Tidak tamat SD (0-6 th) & 6 & 14,27 & 7,8 \\
\hline & SD (7-9 th) & 25 & 59,52 & \\
\hline & SMP (10-12) & 10 & 23,81 & \\
\hline & SMA $(>12$ th $)$ & 1 & 2,40 & \\
\hline Pengalaman & Sangat rendah $(<13$ th $)$ & 20 & 47,63 & 19,17 \\
\hline \multirow[t]{3}{*}{ Berusahatani } & Rendah (13-26 th) & 6 & 14,28 & \\
\hline & Sedang (27-40 th) & 14 & 33,33 & \\
\hline & Tinggi ( $>40$ th) & 2 & 4,76 & \\
\hline \multirow[t]{4}{*}{ Luas lahan } & Sangat rendah $(<0,1$ ha $)$ & 5 & 11,90 & 0,3125 \\
\hline & Rendah $(0,1-0,49$ ha $)$ & 27 & 64,28 & \\
\hline & Sedang $(0,5-1$ ha $)$ & 7 & 16,67 & \\
\hline & Tinggi (> 1 hektar) & 3 & 7,15 & \\
\hline
\end{tabular}

\section{Pengalaman Usahatani}

Pengalaman usaha merupakan lama waktu yang telah digunakan responden dalam usahatani padi sawah. Pengalaman berusahatani padi responden dalam penelitian ini berada pada kategori sangat rendah yaitu 47,73 persen. Hal ini menunjukkan bahwa umumnya petani padi di wilayah Kecamatan Tamansari dalam usahatani padi masih berada dibawah tiga belas tahun. Petani tersebut pada dasarnya merupakan petani baru (petani muda dan beralih profesi) dan petani yang beralih dari hortikultura ke tanaman 
Budi Sawitri dan Hatipah Nurtilawati, Kapasitas Petani Padi dalam Penerapan Teknologi Pengelolaan Tanaman Terpadu (PTT) di Kecamatan Tamansari Kabupaten Bogor Jawa Barat

pangan. Namun demikian banyak juga petani yang memiliki pengalaman usahatani pada kategori sedang, kondisi ini disebabkan karena bertani padi merupakan pekerjaan utama dari petani.

Lama berusahatani merupakan salah satu indikator yang secara tidak langsung turut mendukung keberhasilan berusaha tani secara keseluruhan. Pengalaman petani mendorong kemampuan petani untuk memahami gejala alam yang mempengaruhi kegiatan usahataninya dan kemampuan mereka dalam mengambil keputusan bagi usahataninya. Analisis dan intuisi petani yang memiliki pengalaman tinggi akan cukup tajam karena mereka telah melalui berbagai situasi dalam bertani. Petani yang telah berpengalaman dan yang didukung oleh sarana produksi yang lengkap akan lebih mampu meningkatkan produktivitas jika dibandingkan dengan petani yang baru berusahatani. Pengalaman berusaha tani dapat membentuk perilaku dan kemampuan petani dalam mengelola usaha pertanian. Sesuai dengan pendapat Aminah (2015) bahwa semakin tinggi pengalaman petani dalam berusahatani, maka akan semakin banyak mereka mengalami proses belajar sehingga semakin tahu, cermat, dan memahami berbagai masalah dalam usahatani.

\section{Luas Lahan}

Luas lahan merupakan luasan kepemilikan lahan yang dikelola petani dalam usahatani padi sawah. Luas lahan petani dalam penelitian ini berada pada kategori rendah yaitu 64,28 persen. Lahan pertanian yang dimaksud dalam penelitian ini adalah tanah yang disiapkan untuk diusahakan sebagai usahatani, misalnya lahan sawah, tegalan dan perkarangan. Ukuran lahan pertanian dinyatakan dalam hektar, akan tetapi petani di wilayah penelitian sering menggunakan istilah meter persegi. Rata-rata luas lahan sawah petani responden adalah $0,3125 \mathrm{Ha}$.

Luas lahan sangat menentukan efisiensi produksi dan keuntungan yang diterima petani dari komoditi pangan yang ditanam. Senada dengan pernyataan Aminah (2015) bahwa tingkat penguasaan lahan yang tinggi merupakan faktor penting dalam mengoptimalkan produksi pangan dalam mendukung ketahanan pangan. Namun rata-rata petani di wilayah penelitian memiliki lahan dalam kategori luasan rendah. Luasan lahan tersebut merupakan luas lahan yang digarap oleh petani, yang rata-rata merupakan lahan sewa. Sementara besaran luas lahan dimiliki petani berasal dari warisan turun temurun atas lahan pertanian yang dimiliki keluarga. Petani di wilayah penelitian merupakan petani yang memiliki kemauan yang kuat untuk berusahatani, sehingga mereka selalu berusaha untuk menerapkan praktek pertanian yang baik untuk meningkatkan produktivitas usahatani mereka.

\section{Dukungan Penyuluhan}

Dukungan penyuluhan merupakan faktor-faktor yang berasal dari luar diri petani yang berpengaruh terhadap kapasitas. Berdasarkan data bahwa dukungan penyuluh yang terdiri dari intensitas penyuluhan dan kesesuaian materi penyuluhan serta kemampuan penyuluh tergolong sedang. Dukungan penyuluhan dapat dilihat pada Tabel 2.

\section{Kesesuaian Materi}

Kesesuaian materi penyuluhan merupakan pesan yang disampaikan pada kegiatan belajar petani yang didasarkan pada kebutuhan petani. Berdasarkan hasil penelitian kesesuaian materi penyuluhan yang disampaikan penyuluh tergolong sedang yaitu 52,38 
Budi Sawitri dan Hatipah Nurtilawati, Kapasitas Petani Padi dalam Penerapan Teknologi Pengelolaan Tanaman Terpadu (PTT) di Kecamatan Tamansari Kabupaten Bogor Jawa Barat

persen. Hal ini berarti bahwa setengah dari responden menyatakan bahwa materi penyuluhan yang disampaikan pada saat penyuluhan sesuai dengan prosedur dan kriteria tertentu.

Tabel 2 Dukungan Penyuluhan terhadap Peningkatan Kapasitas

\begin{tabular}{ccccc}
\hline $\begin{array}{c}\text { Dukungan } \\
\text { Penyuluhan }\end{array}$ & Kategori & $\begin{array}{c}\text { Jumlah } \\
(\mathbf{n = 4 2})\end{array}$ & $\begin{array}{c}\text { Persentase } \\
(\boldsymbol{\%})\end{array}$ & Rataan \\
\hline Kesesuaian & Rendah $(13-<16,3)$ & 12 & 28,57 & 17,98 \\
Materi & Sedang $(16,3-<19,6)$ & 22 & 52,38 & \\
& Tinggi $(19,6-23)$ & 8 & 19,05 & \\
Intensitas & Rendah $(7-<8,6)$ & 17 & 40,48 & 8,93 \\
Penyuluhan & Sedang $(8,6-<10,3)$ & 19 & 45,24 & \\
& Tinggi $(10,3-12))$ & 6 & 14,29 & \\
Kemampuan & Rendah $(10-<12)$ & 16 & 38,10 & \multirow{2}{*}{12,26} \\
Penyuluh & Sedang $(12-<14)$ & 12 & 28,57 & \\
& Tinggi $(14-16)$ & 14 & 33,33 & \\
\hline
\end{tabular}

Materi penyuluhan yang paling banyak diminati adalah pengaturan jarak tanam dengan sistem jajar legowo dan pemberian bahan organik, hal ini ditunjukkan dengan 97,62 persen petani menyatakan bahwa materi pengaturan jarak tanam sesuai dengan kebutuhan petani dan materi pemberian bahan organik sejumlah 92,86 persen. Hal ini sejalan dengan permasalahan yang dihadapi petani selama ini. Sistem pengaturan jarak tanam konvensional memiliki kelemahan diantaranya pada saat pemeliharaan (pemupukan, penyiangan, dan pengendalian OPT) dan banyaknya tenaga kerja yang diperlukan saat pengaturan jarak tanam. Pemeliharaan pada sistem tanam konvensioanl menyebabkan banyak kehilangan hasil karena banyak tanaman rusak.

Inovasi tentang pengaturan jarak tanam jajar legowo selain merupakan teknologi untuk pemecahan masalah petani, juga mampu menaikkan produksi dan produktivitas. Hal ini sesuai dengan hasil penelitian Nararya et al. (2017) bahwa sistem tanam jajar legowo 2:1 mampu memberikan hasil GKG yang nyata lebih tinggi dibandingkan model SRI dan konvensional. Sistem tanam jajar legowo 2:1 dapat meningkatkan produktivitas padi sebesar 53\% jika dibandingkan sistem tanam konvensional.

Pemberian bahan organik pada tanah pada dasarnya juga mampu menjawab permasalahan produktivitas lahan yang sudah menurun akibat penggunaan bahan-bahan kimia. Walaupun belum sepenuhnya penggunaan bahan organik diterapkan dalam usahatani padi sawah di wilayah penelitian ini, setidaknya penerapan penggunaan pupuk dapat dikombinasikan dan disesuaikan dengan kebutuhan tanaman dengan pemanfaatan bahan organik yang tersedia dilingkungan wilayah penelitian. Tujuannya untuk meningkatkan kesuburan tanah kembali. Ketersediaan bahan organik di wilayah penelitian rata-rata adalah kompos jerami. Menurut Kaya (2013) bahan organik yang berasal dari kompos jerami dapat sebagai bahan pensuplai berbagai unsur hara $(\mathrm{C}, \mathrm{N}, \mathrm{P}$, $\mathrm{K}$, S, dan senyawa lainnya) sehingga mampu meningkatkan $\mathrm{N}$ tanah. 
Budi Sawitri dan Hatipah Nurtilawati, Kapasitas Petani Padi dalam Penerapan Teknologi Pengelolaan Tanaman Terpadu (PTT) di Kecamatan Tamansari Kabupaten Bogor Jawa Barat

\section{Intensitas Penyuluhan}

Intensitas penyuluhan merupakan jumlah kegiatan pendidikan nonformal yang dilakukan oleh penyuluh. Intensitas penyuluhan berada pada kategori sedang yaitu 45,24 persen. Intensitas penyuluhan diukur dari seberapa sering kegiatan penyuluhan diselenggarakan di lokasi penelitian dan seberapa sering penyuluh mendatangi petani diluar jadwal penyuluhan yang telah ditentukan. Distribusi petani berdasarkan intensitas penyuluhan disajikan dalam Tabel 2.

Penyelenggaraan penyuluhan di Kecamatan Tamansari Kabupaten Bogor dilakukan oleh Balai Penyuluhan Pertanian Wilayah V Dramaga. Kegiatan penyuluhan dilaksanakan oleh BPP dengan berpedoman pada Programa Penyuluhan yang telah disusun. Kemudian, penyuluh secara rutin melaksanakan kegiatan penyuluhan sesuai dengan jadwal yang tertuang dalam RKTP.

Metode yang ditentukan untuk mempercepat transfer teknologi yang disusun dalam perencanaan tersebut adalah Sekolah Lapang. Namun dalam pertemuan rutin kelompok tani, yang diselenggarakan setiap 1-2 minggu sekali, terkadang penyuluh juga menyisipkan penyuluhan tentang PTT walaupun hanya pada komponen-komponen tertentu saja.

Penyuluhan dengan metode Sekolah Lapang PTT Padi yang pernah diterapkan di wilayah penelitian tidak dihadiri oleh semua petani, namun perwakilan 4-5 orang dari masing-masing kelompok tani. Pada pertemuan rutin yang disepakati pun terkadang tingkat kehadiran petani juga rendah, sehingga hal ini menyebabkan tingkat persepsi petani dalam intesitas penyuluhan jadi beragam.

Mengacu pada RKTP, maka kegiatan penyuluhan dibenturkan kepada anggaran. Jika ada anggaran maka kegiatan penyuluhan akan berjalan secara terstruktur dan lancar. Namun demikian penyuluh tidak serta merta bergantung pada anggaran yang ditetapkan oleh Dinas. Penyuluh sering melakukan kunjungan ke wilayah binaan diluar jadwal yang telah disepakati bahkan ketika penyuluh diperlukan untuk mengatasi permasalahan usahatani padi yang menerapkan teknologi PTT. Ukuran sering yang digunakan dalam penelitian ini adalah dalam kurun waktu bulan, mengingat wilayah binaan penyuluh di BPP ini rata-rata memiliki dua desa binaan.

Kondisi wilayah binaan penyuluh yang lebih dari satu wilayah ini yang diduga mengakibatkan intensitas penyuluhan rendah cenderung sedang di wilayah penelitian. Beragamnya materi penyuluhan juga menentukan intensitas penyuluhan, karena materi yang disampaikan ke petani tidak hanya tentang teknologi PTT saja. Hal ini berdampak pada persepsi petani terhadap intensitas penyuluhan. Fakta di lapangan juga menunjukkan bahwa jumlah penyuluh di Kabupaten Bogor belum bisa memenuhi amanat UU SP3K bahwa idealnya penyuluh berkerja pada satu desa. Hal ini senada dengan penelitian Rimbawati (2017) bahwa terbatasnya jumlah penyuluh serta wilayah kerja yang luas menyebabkan rendahnya kunjungan penyuluh.

Padahal semakin sering dilakukan penyuluhan pada dasarnya dapat membuat kelompok tani menjadi semakin dinamis karena adanya interaksi yang terjadi untuk memecahkan permasalahan yang dihadapi dalam penerapan PTT pada padi sawah. Hal ini seperti menurut Kusnani et al. (2015), intensitas penyuluhan berhubungan sangat nyata dan positif dengan dinamika kelompok. Semakin sering dilakukannya penyuluhan dalam kelompok, maka akan semakin tinggi interaksi dalam kelompok melalui kegiatan penyuluhan. 
Budi Sawitri dan Hatipah Nurtilawati, Kapasitas Petani Padi dalam Penerapan Teknologi Pengelolaan Tanaman Terpadu (PTT) di Kecamatan Tamansari Kabupaten Bogor Jawa Barat

\section{Kemampuan Penyuluh}

Kemampuan penyuluh merupakan kemampuan personal, profesional dan kemampuan sosial. Kemampuan penyuluh dalam mentransfer teknologi PTT berada pada kategori sedang. Kondisi ini menunjukkan bahwa persepsi petani terhadap kemampuan penyuluh dalam kegiatan penyuluhan sangat beragam. Hasil penelitian menunjukkan bahwa secara teknis penyuluh mampu dalam transfer teknologi, hal ini ditunjukkan dari 97 persen petani, menilai penyuluh mampu mempraktekkan dan memberikan contoh pada saat penyuluhan. Tidak hanya menyampaikan materi dalam bentuk ceramah saja, namun penyuluh juga memberikan contoh praktek setiap komponen teknologi PTT. Sebagai contoh pengaturan jarak tanam, praktek yang dilakukan yaitu dengan terjun ke sawah dan membuat contoh pola jarak tanam jajar legowo. Dalam memilih benih bermutu, petani diajari cara menentukan benih bernas dan yang tidak rusak dengan menunjukkan ciricirinya. Menghitung estimasi produksi dan produktivitas dengan mengambil sampel tanaman siap panen, kemudian dihitung jumlah malai, jumlah butir permalai, ditimbang dan dihitung perkiraan produksi serta produktivitasnya. Hal ini sesuai pendapat (Narso et al. 2012) bahwa penyuluh pertanian lapang yang berhubungan langsung dengan petani, dituntut untuk menguasai berbagai metode penyuluhan, dapat menerapkannya dengan baik, dan mampu memadukan berbagai jenis metode dalam setiap pertemuan dengan petani.

Kemampuan penyuluh dalam memberikan motivasi untuk menerapkan teknologi PTT kepada petani terlihat dari cara membangun kerjasama dengan petani untuk tidak terlalu bergantung pada program pemerintah saja, namun sedapat mungkin berswadaya dalam mengembangkan usahatani baik secara individu maupun kelompok. Hal lain yang terlihat adalah dengan biaya swadaya kelompok, para petani membuat alat tanam jajar legowo yang dijadikan inventaris kelompok. Pemberian motivasi pengelolaan manajemen kelompok yang dilakukan penyuluh ini mendorong semangat petani sehingga mau untuk berusahatani lebih baik.

\section{Peran Kelompok Tani}

Kelompok tani secara filosofis dibentuk dalam rangka pemecahan permasalahan yang dihadapi petani yang tidak mampu diselesaikan secara individu. Kelompok tani ini merupakan salah satu upaya pemberdayaan petani untuk meningkatkan produksi, produktivitas, dan kesejahteraan petani. Transfer teknologi pertanian akan lebih efisien jika dilakukan pada kelompok tani, karena dapat menjangkau lebih banyak petani dalam satuan waktu tertentu. Peran kelompoktani dalam pengembangan kapasitas individu petani sangat penting terutama dalam penerapan teknologi PTT, peran kelompok dapat digambarkan melalui keaktifan dalam menggerakkan anggota, menjalin kerjasama internal, membangun jejaring pemasaran, permodalan dan kemampuan mengakses program bantuan baik pemerintah maupun swasta (Tabel 3).

Pada tabel 3 menunjukkan bahwa peran kelompok dalam keaktifan menggerakkan anggota, wadah belajar, pemasaran, permodalan dan akses program bantuan cenderung sedang, hanya peran kelompok tani dalam menjalin kerjasama yang memiliki kategori cenderung tinggi. Teknologi PTT yang diintroduksikan kepada kelompok merupakan pengungkit kelompok dalam adopsi teknologi.

Berbagai teknologi yang dianjurkan dalam PTT seperti penggunaan varitas unggul baru, benih bermutu dan bersertifikat, pemberian pupuk organik, pengaturan jarak 
Budi Sawitri dan Hatipah Nurtilawati, Kapasitas Petani Padi dalam Penerapan Teknologi Pengelolaan Tanaman Terpadu (PTT) di Kecamatan Tamansari Kabupaten Bogor Jawa Barat

tanam, pemupukan berimbang, dan pengendalian OPT secara PHT hanya akan efektif jika dilakukan secara bersama-sama oleh anggota kelompok tani. Hal ini dikarenakan jika dilakukan oleh petani secara individu tanpa adanya tindakan untuk memperkuat, meyatukan, dan memperteguh hubungan kelompok, maka tidak akan memberikan hasil sesuai yang diharapkan.

Gambaran peran kelompoktani di wilayah penelitian berada pada kategori cenderung sedang, dilihat dari seluruh rataan setiap indikatornya. Peran kelompok tani yang direfleksikan dari keaktifan menggerakkan anggota kelompok, menjalin kerjasama dan wadah belajar ditunjukkan dengan partisipasi anggota kelompok dalam kegiatan penyuluhan, walaupun yang hadir hanya sekitar 40-50 persen dari total keanggotaan kelompok namun dengan adanya pertemuan rutin dan adanya informasi tentang bantuan pemerintah maupun swasta mendorong kemauan anggota untuk hadir dalam pertemuan. Keaktifan diskusi oleh beberapa anggota kelompok juga menunujukkan tingkat ketertarikan terhadap inovasi yang disampaikan oleh penyuluh. Hasil observasi menunjukkan bahwa petani ketika diskusi membahas suatu masalah terkadang hingga lupa waktu.

\begin{tabular}{|c|c|c|c|c|}
\hline Peran Poktan & Kategori & Jumlah $(n=42)$ & Persentase (\%) & Rataan \\
\hline \multirow[t]{3}{*}{ Keaktifan } & Rendah (2) & 14 & 33,33 & 2,82 \\
\hline & Sedang (3) & 22 & 52,38 & \\
\hline & Tinggi (4) & 6 & 14,29 & \\
\hline \multirow[t]{3}{*}{ Kerjasama } & Rendah $(1-<2)$ & 2 & 4,76 & 2,67 \\
\hline & Sedang $(2-<3)$ & 18 & 42,86 & \\
\hline & Tinggi (3-4) & 22 & 52,38 & \\
\hline \multirow[t]{3}{*}{ Wadah belajar } & Rendah (2) & 4 & 9,52 & 3,33 \\
\hline & Sedang (3) & 20 & 47,62 & \\
\hline & Tinggi (4) & 18 & 42,86 & \\
\hline \multirow[t]{3}{*}{ Pemasaran } & Rendah $(1-<2)$ & 2 & 4,76 & 2,38 \\
\hline & Sedang $(2-<3)$ & 25 & 59,52 & \\
\hline & Tinggi (3-4) & 15 & 35,71 & \\
\hline \multirow[t]{3}{*}{ Permodalan } & Rendah $(1-<2)$ & 6 & 14,29 & 2,10 \\
\hline & Sedang $(2-<3)$ & 24 & 57,14 & \\
\hline & Tinggi (3-4) & 12 & 28,57 & \\
\hline \multirow[t]{3}{*}{ Akses program } & Rendah $(1-<2)$ & 2 & 4,76 & 2,60 \\
\hline & Sedang $(2-<3)$ & 21 & 50,00 & \\
\hline & Tinggi (3-4) & 19 & 45,24 & \\
\hline
\end{tabular}

Dari persepsi petani terhadap peran kelompoktani menunjukkan bahwa dalam penerapan teknologi PTT pada usahatani padi, kelompok tani hanya berperan dalam menggerakkan anggota, membangun kerjasama antar anggota dan kelompok sebagai wadah belajar. Sementara dalam hal pemasaran, permodalan dan mengakses program bantuan peran kelompoktani masih kurang. 
Budi Sawitri dan Hatipah Nurtilawati, Kapasitas Petani Padi dalam Penerapan Teknologi Pengelolaan Tanaman Terpadu (PTT) di Kecamatan Tamansari Kabupaten Bogor Jawa Barat

\section{Tingkat Kapasitas Petani}

Tingkat kapasitas petani dalam penerapan teknologi PTT pada usahatani padi sawah diukur dari penerapan inovasi, penyelesaian masalah, perencanaan usaha tani, evaluasi dan adaptasi teknologi. Kemampuan petani dalam teknis penerapan inovasi cenderung tinggi dan evaluasi usahatani berada dalam kategori sedang. Pada indikator kemampuan pemecahan masalah, perencanaan usahatani dan adaptasi teknologi berada pada kategori rendah. Kapasitas petani dalam penerapan PTT disajikan pada Tabel 4.

Kemampuan teknis petani dalam menerapkan inovasi berada pada kategori sedang cenderung tinggi, hal ini menunjukkan bahwa rata-rata petani sudah mampu melakukan teknologi dasar PTT diantaranya yaitu penggunaan varietas unggul baru dan bermutu, pemberian bahan organik, pengaturan jarak tanam, pemupukan sesuai kebutuhan, dan pengendalian OPT dengan pendekatan PHT. Walaupun belum sepenuhnya teknologi dasar ini diterapkan oleh petani, namun setidaknya petani sudah memliki pengetahuan tentang teknis penerapan PTT.

Kemampuan memecahkan masalah berada pada kategori rendah, hal ini berarti bahwa rata-rata petani belum mampu menyelesaikan sendiri permasalahan yang dihadapi dalam usahatani. Petani masih bergantung pada informasi yang disampaikan oleh penyuluh, terutama dalam menghadapi kelangkaan pupuk, ketersediaan bahan organik, pengendalian OPT, dan kerjabakti dalam pembersihan air irigasi saat menanam padi.

Tabel 4 Kapasitas petani dalam penerapan teknologi PTT

\begin{tabular}{ccccc}
\hline Kapasitas Petani & Kategori & $\begin{array}{c}\text { Jumlah } \\
(\mathbf{n = 4 2})\end{array}$ & $\begin{array}{c}\text { Persentase } \\
(\mathbf{\%})\end{array}$ & Rataan \\
\hline Teknis Penerapan & Rendah $(12-<16)$ & 12 & 28,57 & 18,10 \\
Inovasi & Sedang $(16-<20)$ & 15 & 35,71 & \\
& Tinggi $(20-14)$ & 15 & 35,71 & \\
Pemecahan Masalah & Rendah $(8-<10)$ & 18 & 42,86 & 10,21 \\
& Sedang $(10-<12)$ & 13 & 30,95 & \\
& Tinggi $(12-14)$ & 11 & 26,19 & \\
Perencanaan usahatani & Rendah $(6-<9,3)$ & 20 & 47,62 & 10,69 \\
& Sedang $(9,3-<12,6)$ & 6 & 14,29 & \\
Evaluasi usahatani & Tinggi $(12,6-16)$ & 16 & 38,10 & \\
& Rendah $(6-<8,6)$ & 8 & 19,05 & 10,21 \\
& Sedang $(8,6-<11,2)$ & 22 & 52,38 & \\
Adaptasi teknologi & Tinggi $(11,2-14)$ & 12 & 28,57 & \\
& Rendah $(6-<9,3)$ & 20 & 47,62 & 10,21 \\
& Sedang $(9,3-<12,6)$ & 14 & 33,33 & \\
& Tinggi $(12,6-16)$ & 8 & 19,05 & \\
\hline
\end{tabular}

Kemampuan perencanaan usahatani cenderung rendah dikarenakan petani belum atau tidak melakukan pencatatan kegiatan usahataninya. Dalam merencanakan luasan lahan untuk bertanam padi disesuaikan dengan luasan lahan yang digarap, sehingga hampir semua petani selalu merencanakan luasan lahan. Begitupun dengan rencana biaya dan 
Budi Sawitri dan Hatipah Nurtilawati, Kapasitas Petani Padi dalam Penerapan Teknologi Pengelolaan Tanaman Terpadu (PTT) di Kecamatan Tamansari Kabupaten Bogor Jawa Barat

resiko yang dihadapi. Namun kelemahan petani tidak melakukan pencatatan secara rinci kegiatan yang dilakukan termasuk keuangan.

Indikator kemampuan evaluasi dalam usahatani padi sawah pada penerapan PTT berada pada kategori sedang, artinya bahwa petani sudah bisa membanding-bandingkan hasil produksi yang diperoleh. Hal ini mengindikasikan bahwa sebagian petani secara tidak langsung telah menganalisa dengan menghitung untung rugi hasil usahataninya. Apabila mengalami penurunan produksi petani akan mencari informasi ke penyuluh dan mendiskusikan penyebab penurunan produksi. Namun untuk mencari solusi melalui media lain misalnya leaflet, folder, petunjuk teknis, dan lain-lain masih jarang dilakukan oleh petani.

Kemampuan adaptasi teknologi petani juga cenderung rendah. Hal ini dikarenakan petani jarang mencari solusi ketika keuntungan yang dihasilkan tidak sesuai dengan yang diharapkan dan jarang juga yang mau mengikuti Asuransi Usahatani Pertanian. Terkait dengan teknis teknologi petani rata-rata sering mengadopsi teknologi yang dianjurkan seperti penggunaan benih varietas unggul. Namun untuk teknologi pembuatan pupuk organik petani masih enggan mengadopsi dikarenakan dirasa kurang efektif dan membutuhkan waktu yang relatif lama.

Jika kemampuan petani ditingkatkan dengan baik maka kemampuan tersebut akan mendorong peningkatan produksi, produktivitas, pendapatan, dan efisiensi usahatani padi. Senada dengan pendapat Suprayitno (2011) bahwa kemampuan petani dalam mengetahui, menguasai, memahami dan melaksanakan kaidah-kaidah teknis pengelolaan usahatani akan meningkatkan kemandirian dan keberhasilan petani.

\section{Faktor-faktor yang mempengaruhi Kapasitas Petani}

Evaluasi model pengukuran dan struktural yang dilakukan terhadap hasil analisis PLS menunjukkan bahwa faktor-faktor yang memengaruhi kapasitas petani padi sawah dalam penerapan teknologi PTT di Kecamatan Tamansari adalah dukungan penyuluhan dan peran kelompok tani.

Peran kelompok tani memiliki pengaruh lebih besar dari pada dukungan penyuluhan dan karakteristik petani. Persamaan model struktural faktor-faktor yang memengaruhi kapasitas petani padi sawah dalam menerapkan teknologi PTT adalah $\mathrm{Y}_{1}=$ $0.388 \mathrm{X}_{2}+0.457 \mathrm{X}_{3}+0.58$, model pengukuran (outer model) disajikan pada Gambar1.

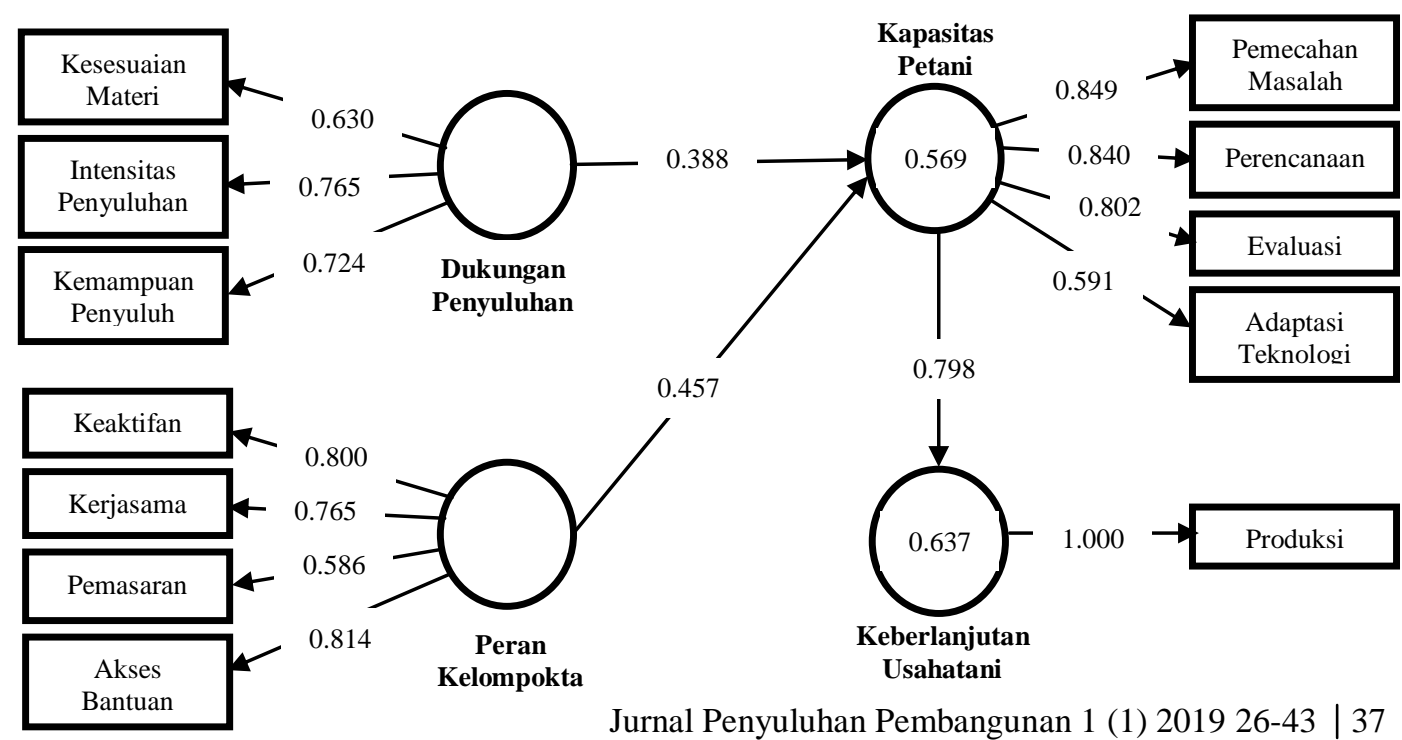


Budi Sawitri dan Hatipah Nurtilawati, Kapasitas Petani Padi dalam Penerapan Teknologi Pengelolaan Tanaman Terpadu (PTT) di Kecamatan Tamansari Kabupaten Bogor Jawa Barat

Gambar 1 Model pengukuran (outer model)

Output path coeffisient dapat dilihat signifikansi pengaruh masing-masing variabel dukungan penyuluhan dan peran kelompoktani terhadap kapasitas petani dengan melihat nilai koefisien parameter (original sample) (Tabel 5). Besar koefisien untuk variabel dukungan penyuluhan $\left(\mathrm{X}_{2}\right)$ sebesar 0,388 yang berarti ada pengaruh positif antara dukungan penyuluhan terhadap kapasitas petani. Atau dapat diinterpretasikan bahwa semakin tinggi dukungan penyuluhan maka kapasitas petani semakin meningkat. Nilai t-hitung (t-statistik) sebesar 2,546 dan t-tabel 2,01 (t-tabel signifikansi 5\% = 2,01). Oleh karena nilai t-hitung lebih besar dari t-tabel maka signifikan, yang artinya dukungan penyuluhan berpengaruh nyata terhadap peningkatan kapasitas petani.

Besar koefisien untuk variabel peran kelompok tani $\left(\mathrm{X}_{3}\right)$ sebesar 0,457 yang berarti ada pengaruh positif antara peran kelompok tani terhadap kapasitas petani. Atau dapat diinterpretasikan bahwa semakin tinggi peran kelompok tani maka kapasitas petani akan semakin meningkat. Nilai t-hitung (t-statistik) sebesar 3,000 dan t-tabel 2,01 (t-tabel signifikansi $5 \%=2,01)$. Oleh karena nilai t-hitung lebih besar dari t-tabel maka signifikan, yang artinya peran kelompok tani berpengaruh nyata terhadap peningkatan kapasitas petani.

Tabel 5 Nilai signifikansi (path coeffisient) peubah laten kapasitas petani

\begin{tabular}{clccc}
\hline No & \multicolumn{1}{c}{$\begin{array}{c}\text { Matriks pengaruh } \\
\text { masing-masing peubah laten }\end{array}$} & $\begin{array}{c}\text { Koefisien } \\
\text { jalur }\end{array}$ & $\begin{array}{c}\text { T- } \\
\text { Hitung }\end{array}$ & Sig. \\
\hline 1 & Dukungan penyuluhan terhadap kapasitas petani & 0.388 & 2.546 & Signifikan \\
2 & Peran kelompoktani terhadap kapasitas petani & 0.457 & 3.000 & Signifikan \\
3 & Kapasitas petani terhadap keberlanjutan usaha & 0.798 & 19.240 & Signifikan \\
\hline
\end{tabular}

Keterangan : nilai t-hitung > nilai t-tabel $(2.01)=$ signifikan, $\alpha=5$ persen

Nilai R-Square $\mathrm{Y}_{1}$ sebesar 0,569 dapat dijelaskan bahwa pengaruh dukungan penyuluhan (X2) dan peran kelompok tani (X3) terhadap kapasitas petani (Y1) sebesar 0,569. Artinya bahwa variabel konstruk kapasitas petani dapat dijelaskan oleh variabel dukungan penyuluhan dan peran kelompoktani sebesar 56,9 persen, sedangkan sisanya 43,1 persen dijelaskan oleh variabel lain diluar yang diteliti.

Faktor-faktor yang signifikan mempengaruhi kapasitas petani adalah dukungan penyuluhan dan peran kelompok tani dalam penerapan teknologi PTT pada usahatani padi sawah. Dukungan penyuluhan memberikan pengaruh yang signifikan dalam meningkatkan kapasitas petani, terutama dalam mengatasi permasalahan, kemampuan merencanakan dan mengevaluasi usahatani serta adaptasi teknologi. Hal ini dapat menjelaskan bahwa peran penyelenggaraan penyuluhan menjadi sangat penting dalam meningkatkan kapasitas petani padi sawah. Penyelenggaran penyuluhan tentang inovasi PTT pada padi sawah ternyata juga memberikan pengaruh terhadap kemampuan penyuluh dalam proses penyuluhan dalam meningkatkan kapasitas petani.

Dukungan penyuluhan yang direfleksikan oleh kesesuaian materi, intensitas penyuluhan dan kemampuan penyuluh ternyata berpengaruh nyata terhadap peningkatan kapasitas petani petani pada penerapan teknologi PTT pada usahatani padi sawah. Kemampuan penyuluh yang sedang cenderung tinggi diiringi dengan intensitas kunjungan yang relatif sedang membuat petani termovitasi dalam menerapkan teknologi PTT pada usahatani padi. Persepsi petani terhadap kemampuan penyuluh menunjukkan bahwa penyuluhan yang dilaksanakan mampu membangun dinamika kelompok tani dan 
Budi Sawitri dan Hatipah Nurtilawati, Kapasitas Petani Padi dalam Penerapan Teknologi Pengelolaan Tanaman Terpadu (PTT) di Kecamatan Tamansari Kabupaten Bogor Jawa Barat

anggotanya untuk mengadopsi inovasi PTT padi sawah. Didukung dengan materi yang sesuai dengan kebutuhan petani yang kemudian dikemas dalam metode sekolah lapang salah satunya, menjadikan petani antusias dalam kegiatan-kegiatan penyuluhan.

Dari analisis deskriptif tentang kesesuaian materi menunjukkan bahwa petani memberikan nilai tertinggi pada pemberian bahan organik dan pengaturan jarak tanam. Hal ini sesuai dengan kondisi masalah di lapangan yang mengindikasikan bahwa penggunaan bahan organik dan jarak tanam menjadi permasalahan paling tinggi, namun juga paling murah solusinya. Artinya bahwa permasalahan tersebut pada dasarnya dapat diselesaikan dengan pemanfaatan sumberdaya alam yang ada misalnya kotoran ternak dan jerami yang melimpah menjadi kompos dan pupuk kandang, namun minimnya pengetahuan petani tentang pengolahan bahan organik dan relatif membutuhkan durasi waktu yang lama menyebabkan petani belum mampu menerapkannya.

Terkait dengan adanya pengaruh dukungan penyuluhan terhadap kapasitas petani, kegiatan penyuluhan berpotensi untuk meningkatkan pengetahuan atau wawasan petani dan selanjutnya digunakan sebagai alternatif pengambilan keputusan berusahatani yang efisien dan tetap memelihara lingkungan. Seperti yang dinyatakan Van den Ban dan Hawkins (1999), bahwa penyuluhan dapat membantu seseorang mencapai tujuannya dari berbagai alternatif pengetahuan yang ada sehingga dapat membuat keputusan yang tepat dalam usahataninya sendiri. Peran penyuluh bukan sebagai pihak yang mengambil keputusan bagi petani, melainkan memberikan data dan informasi sehingga petani dapat mengambil keputusan tepat yang diputuskannya sendiri.

Hasil analisis PLS menunjukkan bahwa nilai koefisien faktor peran kelompoktani ini bertanda positif, artinya bahwa peubah memberikan pengaruh positif terhadap peningkatan kapasitas petani. Hal ini mengandung makna bahwa semakin tinggi atau baik peran kelompoktani, maka akan semakin tinggi kapasitas petani. Dari indikator peran kelompok tani tersebut terlihat bahwa indikator peran kelompok tani dalam mengakses bantuan baik dari pemerintah maupun swasta (0.815) merupakan indikator yang paling kuat merefleksikan peran kelompoktani dan diikuti indikator peran dalam menggerakkan anggota kelompok (0.800), kemudian indikator wadah kerjasama (0.765) serta peran dalam pemasaran (0.586).

Hal ini bermakna peran petani dalam mengakses bantuan dan menggerakkan anggota kelompok lebih dominan dalam membentuk peubah peran kelompoktani untuk mempengaruhi kapasitas petani.

Peran kelompok tani dalam mengakses bantuan baik dari pemerintah maupun sawasta merupakan indikator pertama atau paling kuat yang sangat berpengaruh dalam merefleksikan peubah kemampuan dalam memecahkan masalah. Kelompoktani umumnya beranggotakan petani-petani yang ada di sekitar atau satu hamparan. Kelompok mempunyai pengaruh terhadap perilaku anggotanya. Kegiatan dan peran kelompoktani yang belum dirasakan petani dalam kemampuan teknis dalam penerapan inovasi PTT padi sawah yaitu dalam pelaksanaan usahatani rata-rata cenderung bersifat individual dan belum dilakukan secara berkelompok. Kelompoktani belum berfungsi dalam pengambilan keputusan penerapan teknologi dasar PTT pada usahatani padi sawah terutama pada pemberian bahan organik dan pengendalian hama penyakit. Hal ini umum terjadi, karena konsentrasi pengembangan kelompoktani belum mengarah pada upaya-upaya menjaga lingkungan hidup, khususnya lingkungan persawahan yang masih dianggap baik atau tidak tercemar, tetapi lebih diupayakan yang terkait dengan peningkatan produksi. 
Budi Sawitri dan Hatipah Nurtilawati, Kapasitas Petani Padi dalam Penerapan Teknologi Pengelolaan Tanaman Terpadu (PTT) di Kecamatan Tamansari Kabupaten Bogor Jawa Barat

Peran kelompok tani direfleksikan dari kemampuan kelompok dalam menggerakkan anggotanya, sebagai wahana kerjasama, pemasaran dan akses bantuan baik dari pemerintah maupun swasta. Pada dasarnya teknologi PTT yang diintroduksikan kepada kelompok merupakan pengungkit kelompok dalam adopsi teknologi. Berbagai teknologi yang dianjurkan dalam PTT seperti penggunaan varitas unggul baru, benih bermutu dan bersertifikat, pemberian pupuk organik, pengaturan jarak tanam, pemupukan berimbang, dan pengendalian OPT secara PHT hanya akan efektif jika dilakukan secara bersama-sama oleh anggota kelompok tani. Hal ini dikarenakan jika dilakukan oleh petani secara individu tanpa adanya tindakan untuk memperkuat, menyatukan, dan memperteguh hubungan kelompok, maka tidak akan memberikan hasil sesuai yang diharapkan. Dan pada penelitian ini terbukti bahwa peran kelompoktani mampu menjadi pengungkit kemampuan petani dalam usahatani padi sawah.

\section{Pengaruh Kapasitas Petani terhadap Keberlanjutan Usahatani}

Evaluasi model pengukuran dan struktural yang dilakukan terhadap hasil analisis PLS menunjukkan bahwa keberlanjutan usahatani dipengaruhi oleh kapasitas petani. Persamaan model struktural faktor-faktor yang memengaruhi kapasitas petani padi sawah dalam menerapkan teknologi PTT adalah $\mathrm{Y}_{2}=0.798 \mathrm{Y}_{1}+0.58$, model pengukuran (outer model) disajikan pada gambar 5. Pada tabel 5 output path coeffisient dapat dilihat signifikansi pengaruh variabel kapasitas petani terhadap keberlanjutan usahatani dengan melihat nilai koefisien parameter (original sample).

Besar koefisien variabel kapasitas petani $\left(\mathrm{Y}_{1}\right)$ sebesar 0,798 yang berarti ada pengaruh positif antara dukungan penyuluhan terhadap kapasitas petani. Atau dapat diinterpretasikan bahwa semakin tinggi kapasitas petani maka keberlanjutan usahatani semakin meningkat. Nilai t-hitung (t-statistik) sebesar 19,240 dan t-tabel 2,01 (t-tabel signifikansi $5 \%=2,01)$. Oleh karena nilai t-hitung lebih besar dari t-tabel maka signifikan, yang artinya dukungan penyuluhan berpengaruh nyata terhadap peningkatan kapasitas petani.

Nilai R-Square $\mathrm{Y}_{2}$ sebesar 0,637 dapat dijelaskan bahwa pengaruh peran kapasitas petani $\left(\mathrm{Y}_{1}\right)$ terhadap keberlanjutan usahatani $\left(\mathrm{Y}_{2}\right)$ sebesar 0,637. Artinya bahwa variabel konstruk keberlanjutan usahatani dapat dijelaskan oleh variabel kapasitas petani sebesar 63,7 persen, sedangkan sisanya 36,3 persen dijelaskan oleh variabel lain diluar yang diteliti.

Faktor penentu yang mempengaruhi tingkat keberlanjutan usahatani dalam penerapan PTT padi sawah adalah tingkat kapasitas petani $\left(\mathrm{Y}_{1}\right)$. Pengaruh peubah bersifat langsung sebesar 0,62 dan direfleksikan oleh beberapa indikator kapasitas yaitu kemampuan memecahkan masalah $(\lambda=0.849)$, merencanakan $(\lambda=0.840)$ dan mengevaluasi $(\lambda=0.802)$ usahatani dan kemampuan adaptasi $(\lambda=0.591)$ terhadap keberlanjutan usahatani yang direfleksikan oleh tingkat produksi $(\lambda=1.000)$.

Produksi yang dihasilkan dari penerapan PTT pada usahatani padi sawah untuk menunjang keberlanjutan usahatani dipengaruhi oleh kapasitas petani. Semakin baik kapasitas petani dalam penerapan PTT maka akan berpengaruh terhadap peningkatan produksi padi sawah. Kondisi lahan sawah petani rata-rata berada pada luas areal yang relatif rendah yaitu kisaran 0,3 hektar. Namun kemampuan petani dalam memecahkan masalah dengan perencanaan usahatani kemudian mengevaluasi hasil usahatani. Petani secara sederhana telah merencanakan proses usahataninya dengan memperkirakan kebutuhan usahatani. Kebutuhan dalam usahatni seperti tenaga kerja, modal, tanah dan 
Budi Sawitri dan Hatipah Nurtilawati, Kapasitas Petani Padi dalam Penerapan Teknologi Pengelolaan Tanaman Terpadu (PTT) di Kecamatan Tamansari Kabupaten Bogor Jawa Barat

manajemen pertanian. Dengan memperkirakan input dalam produksi setidaknya petani juga memperkirakan hasil yang akan didapatkan. Sesuai dengan penelitian Daniel (2004) menyebutkan bahwa faktor-faktor input produksi pertanian seperti tenaga kerja, modal, lahan dan manajemen usaha mampu meningkatkan output produksi pertanian.

Dengan menjabarkan kegiatan produksi sebagai suatu proses yang melibatkan beberapa faktor didalamnya dan merencanakan sedini mungkin kebutuhan-kebutuhan dalam kegiatan usahatani seperti tenaga kerja, modal, lahan yang dikuasai petani merupakan faktor yang terlibat dalam kegiatan produksi pertanian. Sehingga kegiatan produksi pertanian dapat menghasilkan produksi pertanian yang maksimal. Selain itu manajemen usahatani juga dibutuhkan agar proses produksi berjalan efektif dan efisien sehingga dapat memberikan keuntungan yang lebih tinggi bagi petani.

Peubah kemampuan mengevaluasi usahatani merupakan indikator masuk dalam kategori sedang (Tabel 4). Kemampuan mengevaluasi merupakan kemampuan personal/individu yang penting dimiliki oleh petani, yaitu kemampuan untuk menganalisis/melihat sejauhmana tingkat pengelolaan yang dilakukan dalam usahatani, sehingga mampu memperoleh hasil secara optimal. Hasil analisis menunjukkan bahwa terdapat pengaruh kemampuan evaluasi terhadap peningkatan produksi, artinya bahwa kemampuan evaluasi kegiatan usahatani dalam penerapan usahatani padi sawah yang termasuk dalam kegiatan manajerial dapat memberikan kontribusi pada peningkatan produksi. Menurut Suprayitno (2011) bahwa kemampuan petani dalam mengetahui, menguasai, memahami dan melaksanakan kaidah-kaidah teknis pengelolaan meningkatkan kemandirian dan keberhasilan petani. Senada juga dengan Sadono (2012) bahwa manfaat yang dirasakan selain dari aspek pengetahuan terkait pengelolaan usahatani yang semakin bertambah, juga manfaat dari segi ekonomi di mana petani cukup sering memperoleh informasi pasar.

Tingkat kemampuan beradaptasi terhadap inovasi dalam kategori sedang. Kemampuan beradaptasi yang cukup baik terutama pada kemampuan mencari solusi jika keuntungan tidak sesuai dengan harapan. Kemampuan petani yang relatif rendah adalah dalam hal mengikuti asuransi pertanian karena belum adanya kesadaran bahwa asuransi dapat menjamin keberlanjutan usahataninya jika terjadi gagal panen melalui ganti rugi usahatani. Petani beranggapan asuransi hanya merupakan pengeluaran atau penambahan beban biaya usahatani. Selain itu kemampuan mencari solusi jika terjadi kelangkaan pupuk dengan pembuatan pupuk organik sendiri masih sangat rendah. Hal ini dikarenakan dalam proses pembuatan pupuk organik membutuhkan waktu yang lama dan menurut petani tidak praktis, walaupun bahan baku tersedia.

\section{KESIMPULAN}

Tingkat kapasitas petani dari indikator kemampuan dalam teknis penerapan berada pada kategori sedang cenderung tinggi, kemampuan pemecahan masalah kategori rendah, kemampuan perencanaan usahatani kategori rendah, kemampuan evaluasi kategori sedang dan adaptasi teknologi berada pada kategori rendah.

Faktor-faktor yang mempengaruhi kapasitas petani adalah dukungan penyuluhan dan peran kelompoktani. Dukungan penyuluhan memberikan pengaruh yang signifikan dalam meningkatkan kapasitas petani, terutama dalam mengatasi permasalahan, kemampuan merencanakan dan mengevaluasi usahatani serta adaptasi teknologi. Peran kelompok tani direfleksikan dari kemampuan kelompok dalam menggerakkan 
Budi Sawitri dan Hatipah Nurtilawati, Kapasitas Petani Padi dalam Penerapan Teknologi Pengelolaan Tanaman Terpadu (PTT) di Kecamatan Tamansari Kabupaten Bogor Jawa Barat

anggotanya, sebagai wahana kerjasama, pemasaran dan akses bantuan baik dari pemerintah maupun swasta. Pada dasarnya teknologi PTT yang diintroduksikan kepada kelompok merupakan pengungkit kelompok dalam adopsi teknologi.

Faktor penentu yang mempengaruhi tingkat keberlanjutan usahatani dalam penerapan PTT padi sawah adalah tingkat kapasitas petani. Pengaruh peubah bersifat langsung dan direfleksikan oleh beberapa indikator kapasitas yaitu kemampuan memecahkan masalah, merencanakan dan mengevaluasi usahatani dan kemampuan adaptasi terhadap keberlanjutan usahatani yang direfleksikan oleh tingkat produksi.

\section{DAFTAR PUSTAKA}

Aminah S. 2015. Pengembangan Kapasitas Petani Kecil Lahan Kering Untuk Mewujudkan Ketahanan Pangan. Jurnal Bina Praja Volume 7 No.3 Edisi September 2015 : 197-210. [Internet]. [diacu 5 Oktober 2018]. Tersedia dari : http://binaprajajournal.com.

[Balitbangtan] Badan Penelitian dan Pengembangan Pertanian. 2009. Pedoman Umum PTT Padi Sawah. Jakarta (ID) : Penerbit Badan Penelitian dan Pengembangan Pertanian.

[Balitbangtan] Badan Penelitian dan Pengembangan Pertanian. 2016. Pedoman Umum PTT Padi Sawah. Jakarta (ID) : Penerbit Badan Penelitian dan Pengembangan Pertanian.

Daniel M. 2004. Pengantar Ekonomi Pertanian. Jakarta (ID) : Bumi Aksara.

Fatchiya A. 2010. Pola Pengembangan Kapasitas Pembudidaya Ikan Kolam Air Tawar di Provinsi Jawa Barat. [Disertasi]. Bogor (ID) : IPB.

Havigust RJ. 1974. Development Tasks and Education. Third Edition. New York (US) : David McKay Company Inc.

Kaya E. 2013. Pengaruh Kompos Jerami dan Pupuk NPK Terhadap N-Tersedia Tanah, Serapam-N, Pertumbuhan, dan Hasil Padi Sawah (Oryza sativa L.). Jurnal Agrologia, Vol.2 No.1, April 2013, Hal. 43-50.

Kusnani DK., Muljono P, Saleh A. 2015. Dinamika Kelompok Penerima CSR PLN Tarahan Lampung Selatan. Jurnal Penyuluhan. 11(2): 129-142.

Leeuwis C dan Van Den Ban A. 2009. Komunikasi Untuk Inovasi Pedesaan Berpikir Kembali tentang Penyuluhan Pertanian.. Yogyakarta (ID) : Kanisius.

Lodismith J, Robert W. 2010. Getting to Know Me : Social Role Experience and Age Differences in Self Concept Clarity During Adulthood. Journal of Personality.78(5).525-540.doi:10.1111/ j.1467-6494.2010.00655.x

Mardikanto T. 1993. Penyuluhan Pembangunan Pertanian. Surakarta (ID) : UNS Press.

Mirza, Amanah S., Sadono D. 2017. Tingkat Kedinamisan Kelompok Wanita Tani dalam Mendukung Keberlanjutan Usaha Tanaman Obat Keluarga di Kabupaten Bogor, Jawa Barat. Jurnal Penyuluhan. 13(2): 181-193.

Nararya MBA, Santoso M, Suryanto A. 2017. Kajian Beberapa Macam Sistem Tanam dan Jumlah Bibit Per Lubang Tanam pada Produksi Tanaman Padi Sawan (Oryza sativa L.) var. Inpari 30. Jurnal Produksi Tanaman Vol.5 No.8, Agustus 2017:1338-1345 ISSN:2527-8452. 
Budi Sawitri dan Hatipah Nurtilawati, Kapasitas Petani Padi dalam Penerapan Teknologi Pengelolaan Tanaman

Terpadu (PTT) di Kecamatan Tamansari Kabupaten Bogor Jawa Barat

Narso, Saleh A., Asngari PS, Muljono P. 2012. Persepsi Penyuluh Pertanian Lapang tentang Perannya dalam Penyuluhan Pertanian Padi di Provinsi Banten. Jurnal Penyuluhan, Maret 2012 Vol.8 No.1.

Padillah, Purnaningsih N, Sadono D. 2018. Persepsi Petani tentang Peranan Penyuluh dalam Peningkatan Produksi Padi di Kecamatan Tabir Kabupaten Merangin Provinsi Jambi. Jurnal Penyuluhan Volume 14 No.1 Maret 2018 ASSN:18582664 EISSN : 2442-4110.

Rimbawati DEM. 2017. Pemberdayaan Masyarakat melalui Pengembangan Kelompok Tani Hutan Agroforestry di Kabupaten Bandung. [Tesis]. Bogor (ID): Program Pascasarjana, Institut Pertanian Bogor.

Sarwono J, Narimawati U. 2015. Membuat Skripsi, Tesis dan Disertasi dengan Partial Least Square SEM (PLS-SEM). Yogyakarta (ID): Penerbit Andi.

Suprayitno A. 2011. Model peningkatan partisipasi petani sekitar hutan dalam mengelola hutan kemiri rakyat: Kasus Pengelolaan Hutan Kemiri Kawasan Pegunungan Bulusaruang. Kabupaten Maros Sulawesi Selatan [Disertasi]. Bogor (ID): Institut Pertanian Bogor.

Van den Ban AW, Hawkins HS. 1999. Penyuluhan Pertanian . Yogyakarta (ID): Kanisius. 